\title{
Flyback Cascaded Multilevel Inverter Based SHE-PWM Control for STATCOM Applications
}

\author{
Kah Haw Law ${ }^{1}$, Wendy Pei Qin $\mathrm{Ng}^{2}$, Wei Kitt Wong ${ }^{3}$ \\ ${ }^{1,3}$ Department of Electrical and Computer Engineering, Curtin University, Sarawak, Malaysia \\ ${ }^{2}$ Departement of Chemical Engineering, Curtin University, Sarawak, Malaysia
}

\author{
Article Info \\ Article history: \\ Received Sep 27, 2016 \\ Revised Dec 03, 2016 \\ Accepted Dec 13, 2016 \\ Keyword: \\ Cascaded H-Bridge inverter \\ (CHI) \\ Reactive power (VAR) \\ Compensation \\ Selective harmonic elimination \\ pulse width modulation \\ (SHEPWM) \\ Static synchronous \\ compensator (STATCOM)
}

\begin{abstract}
This paper presents the closed loop DC-DC flyback converter with multilevel cascaded $\mathrm{H}$-bridge inverter (MCHI) for transformer-less static synchronous compensator (STATCOM) system. The STATCOM system is proposed to be controlled using decoupled dq vector control incorporating the new reactive current reference algorithm and multi-level selective harmonic elimination pulse width modulation (MSHEPWM) technique. This ensures transient performance enhancement as well as simpler control and modulation technique implementation for dynamic systems. As the proposed MSHEPWM solely depends on adjustable DC-link voltage levels, flyback converter is designed for that purpose to suit wider applications. In current work, a single phase five-levels CHI based STATCOM system incorporated with the aforementioned converters are presented to compensate the reactive power (VAR) at the point of common connection (PCC). The dynamic as well as the transient performances of the developed STATCOM control system and the proposed voltage closed loop control of each converter are investigated to meet different VAR demands at balanced loading conditions. Simulation studies are performed to verify the effectiveness and theoretical analysis of the approaches presented.
\end{abstract}

Copyright $\odot 2017$ Institute of Advanced Engineering and Science. All rights reserved.

\section{Corresponding Author:}

Kah Haw Law,

Department of Electrical and Computer Engineering,

Curtin University Sarawak Malaysia,

CDT 250, 98009 Miri, Sarawak, Malaysia.

Email: lawkahhaw@curtin.edu.my

\section{INTRODUCTION}

High penetration of distributed power generation with increased renewable energy capacity has introduced efficiency and power quality concerns into modern power networks due to poor power flow management. These include excessive harmonics, low power factor (PF), power disturbances and power unbalance. Low PF, which is caused by reactive loads, draws excessive VAR. This restricts maximum active power transfer and results in further power losses to the power networks [1]. Power disturbances such as swells, sags, variations and transients that are induced by low PF, non-linear and abrupt load fluctuations commit to electronic components defection, electrical disruption and malfunction of modern process control [2]-[3]. Besides, unequal single phase loads over three phase distribution systems cause unbalanced power flow. This induces additional losses to electrical equipment which restrict their tolerances (i.e., shorter lifespan) in terms of stability and reliability [4]. The aforementioned phenomena also appear to be more significant in weak power system with high grid impedance [3].

Electrical equipment and electronic circuits are susceptible to voltage sags. If the problem is not mitigated, more electricity outages or power interruptions will bring in economic losses for both the customers and the utilities. Therefore, continuous power networks' voltage stability improvement is a must under both normal and contingency operating conditions [5]. These complications can be minimized or even 
eliminated by controlling the VAR. In the past few decades, the rapid growth in power electronics industry has brought in development on the management and operation of the utility power network systems [6]. This led to the development of flexible alternating current transmission system (FACTS) controllers which enhance reliable exchange of power and bring a more economical neighbouring and regional utilities [7]. Particularly, the development of shunt-connected STATCOM has played a major role in FACTS. A conventional STATCOM, which constructed with a PWM switching inverter and DC-link capacitor, can provide quicker response (i.e., in a few cycles) to the changing loading conditions in the power system [8]. For a commercial STATCOM which specifically designed for PF or unbalance power compensation, battery energy storage system (BESS) will be integrated as the DC-link voltage source to store energy and support applications that require high active current compensation [9]. For these reasons, industries install STATCOM in their electric network to improve power quality and achieve long term cost saving.

Extensive researches have been carried out over the last few decades and it is proven that multi-level inverter topologies are capable to overcome problems associated with conventional voltage source inverters (VSIs). Specifically, MCHI turns to be a promising topology in STATCOM application due to its control simplicity, extensibility, modularization and the capability of providing negative sequence current compensation [10]. Besides that, modulation technique as one of the core components of STATCOM affects the compensation objectives, steady-state and transient performances. Therefore, several multi-level PWM techniques have been proposed, researched and documented theoretically. These techniques include carrier based pulse width modulation (CBPWM), SHEPWM and space vector modulation (SVM). Among these techniques, MSHEPWM controls the low order harmonics tightly with relatively low switching frequency; hence, resulting in low switching loss and good total harmonics distortion (THD) performance. Furthermore, appropriate control scheme design influences the performance of a STATCOM to react to power exchange demands promptly with high accuracy. Various control schemes of MCHI based STATCOM have been developed for power regulation using mostly time domain approach to achieve the pre-defined performances due to its capability to calculate reference currents and sensitivity to trace load variation [10].

For instance, Parker et al. proposed a control strategy and a modular boost converter with MCHI to tolerate module faults for large direct drive wind turbine generator [11] with the switching frequency of the rectifier set at $16 \mathrm{kHz}$. When a failed module was detected, it would be bypassed and the boost converter would increase the DC-link voltage of the rest of the modules to hold the reactive power output constant. However, the proposed DC-link voltage controller in response to a step change of voltage demand (i.e., from $690 \mathrm{~V}$ to $750 \mathrm{~V}$ ) takes approximately $250 \mathrm{~ms}$ to reach the steady state condition. A novel five-levels multistring inverter topology was investigated by Liao and Lai for distributed energy resources based DC-AC conversion system [12]. When compared with the conventional boost converter, the novel topology offers lower electromagnetic interference (EMI), lower THD and smaller filter size. However, switching frequency of $85 \mathrm{kHz}$ was employed to keep the bus voltage variation minimum (i.e., $10 \mathrm{~V}$ ). This minimized the thirdorder harmonic occurrence on the AC output voltage. A high power cascaded boost-type converter system for large permanent magnet wind generator system was proposed by Yuan et al. to independently regulate the active and reactive powers of the power network [13]. $8 \mathrm{kHz}$ of switching frequency was used for both the converter and the CHI. However, the THD generated from the CHI was not discussed. Wu and Chou proposed a DC-DC boost power converter with a simplify seven-levels inverter that contains only six switching elements for solar power generation system [14]. With the switching frequency of $15.36 \mathrm{kHz}$, the proposed circuit configuration reduced THD (i.e., 3.6\%) and switching loss whilst improved power efficiency. However, the employment of the dead-band time to prevent the H-bridge cell from short-circuit is not discussed. Another new structure of seven-levels boost DC-link CHI was proposed by Ramasami et al. for uninterrupted power supply (UPS) and drive applications [15]. In comparison to the conventional twostages system, the system structured with less DC source and switch count reduced the voltage stress across the inverter; hence, making the system more cost effective. However, the employment of switching frequency is not discussed. Recently, Zamiri et al. proposed a novel structure for multi-level inverters based switched-capacitor which has the boost ability to generate high voltage levels without using $\mathrm{H}$-bridge cell (i.e., less number of switch) [16]. In summary, the research studies conducted in recent times have not explored the beneficial of utilizing DC-DC flyback converter to form a two-stage inverter topology.

This paper extends the investigation of the MCHI based STATCOM with separated DC-DC flyback converter topology employing the proposed decoupled dq vector control [17] and the new MSHEPWM technique [18]. The control scheme incorporated the new reactive current reference algorithm ensures transient performance enhancement without employing integral controller. In addition, the new technique with constant switching angle and variable DC-link voltage levels across the modulation index $\left(\mathrm{m}_{\mathrm{i}}\right) \mathrm{range}$ guarantees a simpler control implementation and enables more harmonics to be eliminated (i.e., $(N+M)-1$ as opposed to $N-1$ from the conventional MSHEPWM technique) for STATCOM system; where $M$ defines the total units of H-bridge cell per phase-leg and $N$ is the sum of switching angles per quarter cycle. In this work, 
the effectiveness of both the dynamic as well as the transient performances of the proposed STATCOM control scheme [17] and the proposed voltage closed loop control of each converter are presented in selected simulation results. Even though five-levels CHI based STATCOM is presented in this work, nevertheless, it is noteworthy that all the developed methods can be employed regardless of the circuit structure and the number of inverter levels.

\section{FIVE-LEVELS SHE-PWM WITH ADJUSTABLE DC-LINK VOLTAGE LEVELS}

Figure 1 show the proposed single phase five-levels CHI with separated DC-DC flyback converter. From several research articles proposed for different applications, it is noted that integrating a DC-DC converter with relatively high switching frequencies range from $5 \mathrm{kHz}$ [19] to $50 \mathrm{kHz}$ [20] to an inverter will not deteriorate the practicability of the STATCOM. For instance, Akagi and Kitada [21] proposed a modular $6.6 \mathrm{kV}$ multi-level cascaded back-to-back inverter combining bidirectional isolated DC-DC converter operating at switching frequency of $20 \mathrm{kHz}$, which considered acceptable as suggested by enormous recent literature in the field.

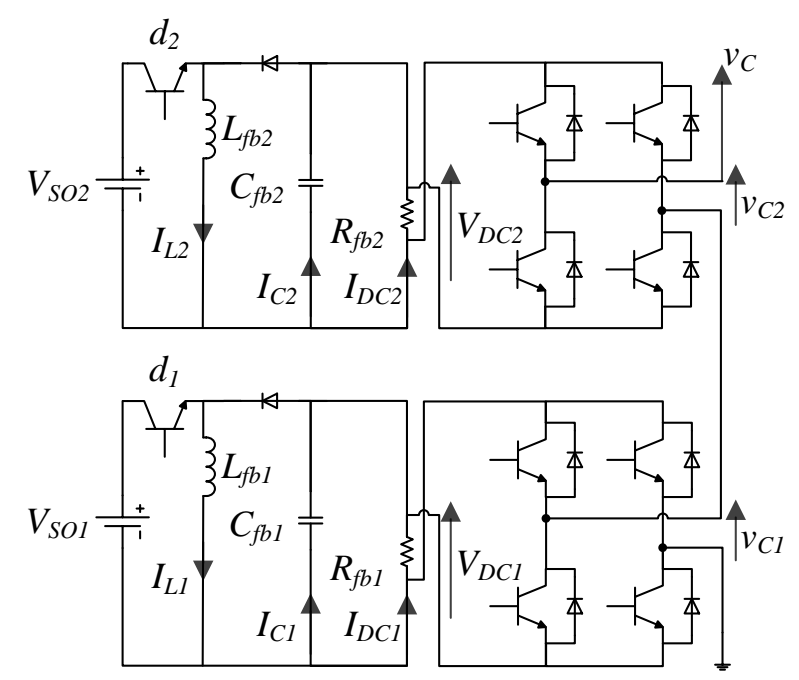

Figure 1. Single phase five-levels CHI with separated DC-DC flyback converter

The flyback converter has an advantage of outputting higher and lower voltage than its input voltage $V_{S O}$ when compared with other DC-DC converter topologies; hence, enabling the STATCOM to provide lagging and leading VAR compensation to the PCC, respectively. This also beneficial to those low levels photovoltaic (PV) based cascaded/non-cascaded converter/inverter system where multiple series-connected PV cells are needed to achieve high power output rating.

The state space equation and the proposed voltage closed loop control for flyback converter is discussed later in this work. In many applications, it is important for a converter/inverter to be lightweight and small size [22]. From Table 2, the flyback is certainly the favorable converters when compared with the buck converter [18] due to its smaller size of $L C$ output filter (see (1) and (2)) possessed by high switching frequency.

$$
\begin{aligned}
L_{f b} & =\frac{V_{S O}}{f_{s w} I_{L_{-} f b}} \\
C_{f b} & =\frac{\frac{1}{2} \times \frac{1}{2 f_{s w}} \times \frac{I_{D C_{-} f b} D}{2}}{0.001 \times V_{D C_{-} f b}}
\end{aligned}
$$


where $V_{D C}$ defines the DC-link voltage and $I_{D C}$ defines the current flowing through converter's resistor $R$. The inductor current for the flyback converter is defined in (3).

$$
I_{L_{-} f b}=\frac{V_{D C_{-} f b}}{R_{f b}} \frac{D}{1-D}=I_{D C_{-} f b} \frac{D}{1-D}
$$

The five-levels SHE-PWM voltage waveform is constructed by constant switching angles with a distribution ratio of 3/8 (i.e., for every quarter-cycle) and linear pattern of DC-link voltage levels over the specify $m_{i}$ range as reported in [18]. This makes the switching frequency of the inverter equals to $2.2 \mathrm{kHz}$ (i.e., 44x50 Hz); hence, ultimately offering substantially less losses, less cooling as well as reducing the weight and the volume of the overall system. Furthermore, the technique effectively eliminates the twelve low order non-triplen harmonics (i.e., $5^{\text {th }}, 7^{\text {th }}, 11^{\text {th }}, 13^{\text {th }}, 17^{\text {th }}, 19^{\text {th }}, 23^{\text {rd }}, 25^{\text {th }}, 29^{\text {th }}, 31^{\text {st }}, 35^{\text {th }}$ and $37^{\text {th }}$ ) while controlling the fundamental component at pre-defined value.

\section{KEY OPERATION OF THE PROPOSED STATCOM}

Figure 2 shows the proposed single phase five-levels SHE-PWM inverter based STATCOM and the associated control schemes. The STATCOM system is connected in parallel to the power network via a coupling impedance $Z_{f}$ at the PCC. In this work, the proposed decoupled dq vector control incorporating the new reactive current reference algorithm $i_{c q}{ }^{*}$ in [17] is employed as the STATCOM main system. As the proposed MSHEPWM technique relies on adjustable DC-link voltage levels, flyback converter, which operates at $25 \mathrm{kHz}$, is specifically considered to generate the required DC voltages for each $\mathrm{H}$-bridge cell base on the resulting modulation index $m_{i}$.

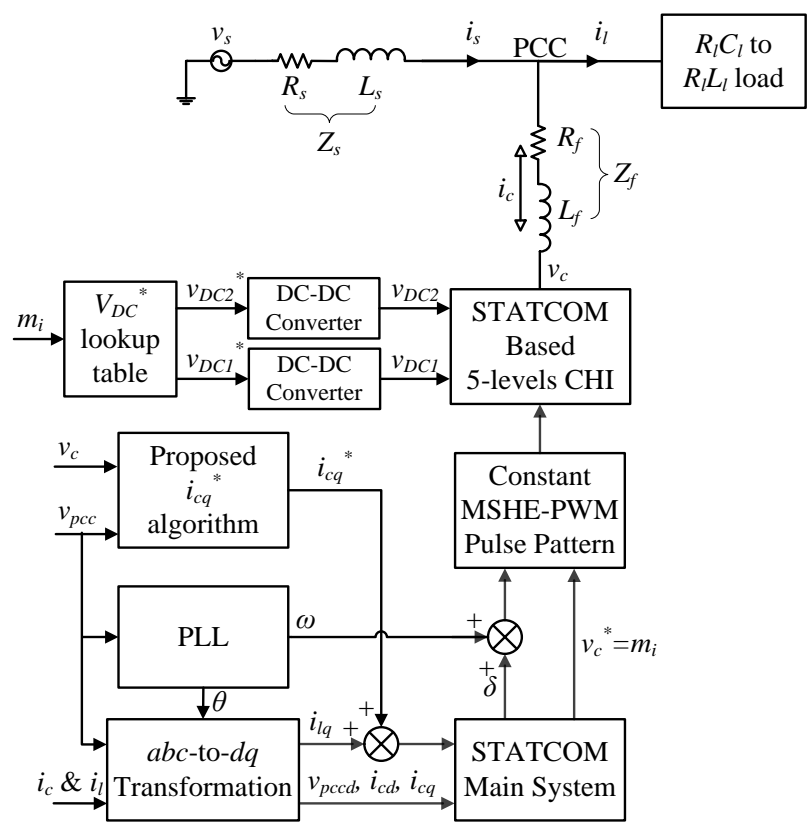

Figure 2. Single line diagram of the proposed single phase STATCOM system

The flyback converter's voltage closed loop control is implemented in continuous conduction mode with the state-space averaging modelling technique. The state-space equation of the flyback converter for mode 1 (i.e., switch is on) and mode 2 (i.e., switch is off) are defined in (4) and (5), respectively.

$$
\left[\begin{array}{c}
\frac{d I_{L_{-} f b}}{D T} \\
\frac{d V_{D C_{-} f b}}{D T}
\end{array}\right]=\left[\begin{array}{cc}
0 & 0 \\
0 & -\frac{1}{R_{f b} C_{f b}}
\end{array}\right]\left[\begin{array}{c}
I_{L_{-} f b} \\
V_{D C_{-} f b}
\end{array}\right]+\left[\begin{array}{c}
1 \\
L_{f b} \\
0
\end{array}\right] V_{S O}
$$




$$
\left[\begin{array}{c}
\frac{d I_{L_{-} f b}}{(1-D) T} \\
\frac{d V_{D C_{-} f b}}{(1-D) T}
\end{array}\right]=\left[\begin{array}{cc}
0 & -\frac{1}{L_{f b}} \\
\frac{1}{C_{f b}} & -\frac{1}{R_{f b} C_{f b}}
\end{array}\right]\left[\begin{array}{c}
I_{L_{-} f b} \\
V_{D C_{-} f b}
\end{array}\right]
$$

By equating (4) and (5), the periodic state-space equation over switching period $t$ is given by:

$$
\frac{d}{d t}\left[\begin{array}{c}
I_{L_{-} f b} \\
V_{D C_{-} f b}
\end{array}\right]=\left[\begin{array}{l}
{\left[\begin{array}{cc}
0 & 0 \\
0 & -\frac{1}{R_{f b} C_{f b}}
\end{array}\right] D} \\
{\left[\begin{array}{cc}
0 & -\frac{1}{L_{f b}} \\
\frac{1}{C_{f b}} & -\frac{1}{R_{f b} C_{f b}}
\end{array}\right](1-D)}
\end{array}\right]\left[\begin{array}{c}
I_{L} \\
V_{D C}
\end{array}\right]+\left[\begin{array}{c}
D \\
L_{\text {booss }} \\
0
\end{array}\right] V_{S O}
$$

From (6), the parameters $D, X=I_{L}$ and $V_{D C}$, as well as $U=V_{S O}$ are redefined as shown in equation (7) after considering the small deviations from a steady-state operating point:

$$
X=>X_{O}+x, D \Rightarrow D_{O}+d, U=>U_{O}+u
$$

where $X_{O}, D_{O}$ and $U_{O}$ are the steady-state operating point while $x, d$ and $u$ define the behaviour of small perturbation terms from the operating point.

The steady-state relationships of the flyback converter are defined by:

$$
V_{D C_{-} f b}=\frac{D_{O}}{1-D_{O}} V_{S O} \quad I_{L_{-} \mathrm{b}}=\frac{V_{S O}}{\left(1-D_{O}\right) R_{L_{-} \mathrm{b}}}
$$

By substituting (7) and (8) into (6), the final linear time-invariant state-space averaged equation of DC output voltage $v_{D C}(s)$, as shown in (9), is obtained after ignoring all the steady-state parameters (i.e., $X_{O}$, $D_{O} X_{O}$ and $U_{O}$ ) and the perturbation terms (i.e., $d x$ ).

$$
v_{D C}(s)=\left(\frac{\frac{\left(1-D_{O}(s)\right) v_{S O}(s)}{V_{S O}(s)}}{1-\frac{s L_{f b}}{\left(1-D_{O}(s)\right)^{2} R_{f b}}}+d(s) \times\left(\frac{\frac{V_{S O}(s)}{\left(1-D_{o}(s)\right)^{2}}\left(1-\frac{s L_{f b}}{\left(1-D_{o}(s)\right)^{2} R_{f b}}\right)}{\frac{s^{2} L_{f b} C_{f b}}{\left(1-D_{O}(s)\right)^{2}}+\frac{s L_{f b}}{\left(1-D_{o}(s)\right)^{2} R_{f b}}+1}\right)\right.
$$

where the first mathematical term describes the flyback converter's input voltage deviation from the steadystate operating point while the second mathematical term defines the flyback converter's transfer function $G_{\text {conv }}(s)$, which is used to design the voltage closed loop controller $G_{v}(s)$.

It is noticed from (9) that the right-half plane zero (i.e., second bracket) is affected by the size of the filter inductance $L_{f b}$. Therefore, in order to diminish the aforementioned zero that caused control instability, high switching frequency $f_{S W}$ is preferred to reduce the effective value of filter inductance $L_{f b}$ in (1) to attain good transient response. The flyback converter's control system is shown in Figure 3 below.

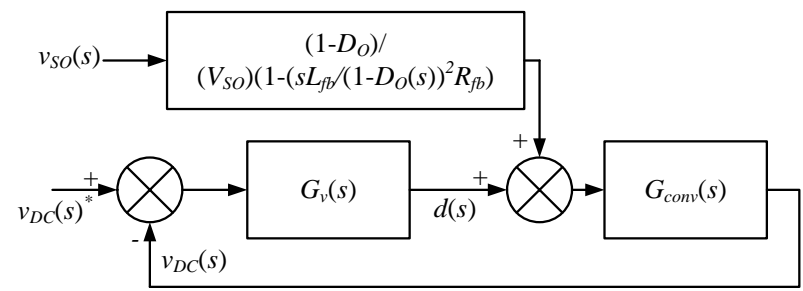

Figure 3. Single line diagram of the proposed voltage closed loop control for DC-DC flyback converter 


\section{SIMULATION RESULTS}

The proposed single phase five-levels SHE-PWM based STATCOM system is studied via simulation modelling using Matlab/Simulink software. The dynamics, steady-state and transient performances of the proposed work are explored with different linear reactive loading conditions that switches from capacitive load A to inductive load B (i.e., from leading to lagging PF) at the time of 1 second (see Table 1).

Table 1. The Proposed Single Phase STATCOM's Parameters Used in Simulation Study

\begin{tabular}{lll}
\hline Parameter & Electrical Units & Per Units \\
\hline Fundamental frequency, $f$ & 50 & - \\
Grid voltage, $v_{p c c}$ & $240 \mathrm{~V}_{\text {rms }}$ & 1 \\
Grid resistor, $R_{s}$ & $0.4 \Omega$ & 0.01 \\
Grid inductor, $L_{s}$ & $12.7 \mathrm{mH}$ & $0.3175 \mathrm{~m}$ \\
Grid impedance, $Z_{s}$ & $4 \Omega$ & 0.1 \\
Coupling resistor, $R_{f}$ & $4 \Omega$ & 0.1 \\
Coupling inductor, $L_{f}$ & $127 \mathrm{mH}$ & $3.175 \mathrm{~m}$ \\
Coupling impedance, $Z_{f}$ & $40 \Omega$ & 1 \\
Load power, $P_{l_{-} A, B}$ & $960 \mathrm{~W}$ & 0.94 \\
Load reactive power, $Q_{l \_A, B}$ & $960 \mathrm{VAR}$ & 0.94 \\
Load current, $i_{l \_A, B}$ & $5.64 \mathrm{~A}$ rms & 0.94 \\
$d q$-axis Proportional gain, $K_{p \_i d, i q}$ & - & 0.25 \\
\hline
\end{tabular}

where the base value of grid's apparent power $S_{\text {base }}=1.44 \mathrm{kVA}$, grid's current $I_{\text {base }}=6 \mathrm{~A}_{\text {rms }}$, grid's impedance $Z_{\text {base }}=40 \Omega$ as well as the apparent power of resistive-capacitive load A $S_{l_{-} A}=1360 \mathrm{~W}$ and resistiveinductive load B $S_{l \_B}=1360 \mathrm{~W}$.

The parameters of the proposed flyback converter, which employed to the five-levels CHI based STATCOM to achieve variable DC-link voltage levels according to $m_{i}$, are tabulated in Table 2. In this work, selected simulation results are generated and analysed to verify the feasibility of the proposed control scheme and MSHEPWM technique applied to STATCOM application.

Table 2. The Proposed DC-DC Converter's Parameters Used in Simulation Study

\begin{tabular}{ll}
\hline Parameter & Electrical Units \\
\hline DC voltage source, $V_{S O}$ & $120 \mathrm{~V}$ \\
Filter inductor, $L$ & $7.5 \mu \mathrm{H}$ \\
Filter capacitor, $C$ & $350 \mu \mathrm{F}$ \\
Filter resistor, $R$ & $1 \Omega$ \\
Steady state duty cycle, $D$ & 0.7 \\
Switching frequency, $f_{S W}$ & $25 \mathrm{kHz}$ \\
Crossover frequency, $\omega_{\text {cross_buck }}$ & $11400 \mathrm{rad} / \mathrm{s}$ \\
Gain of error amplifier, $A$ & 3.38 \\
Zero-frequency, $\omega_{z_{\text {_buck }}}$ & $1668.37 \mathrm{rad} / \mathrm{s}$ \\
Pole-frequency, $\omega_{\text {p_buck }}$ & $77917 \mathrm{rad} / \mathrm{s}$ \\
\hline
\end{tabular}

Figure 4 shows the single phase five-levels SHE-PWM voltage waveform and its associated harmonic spectrum generated by the proposed STATCOM with separated flyback converters on load B. It is examined that the low order non-triplen harmonics as stated in Section 2 have been eliminated and the next harmonic that shows in the frequency spectrum is $41^{\text {st }}$. 

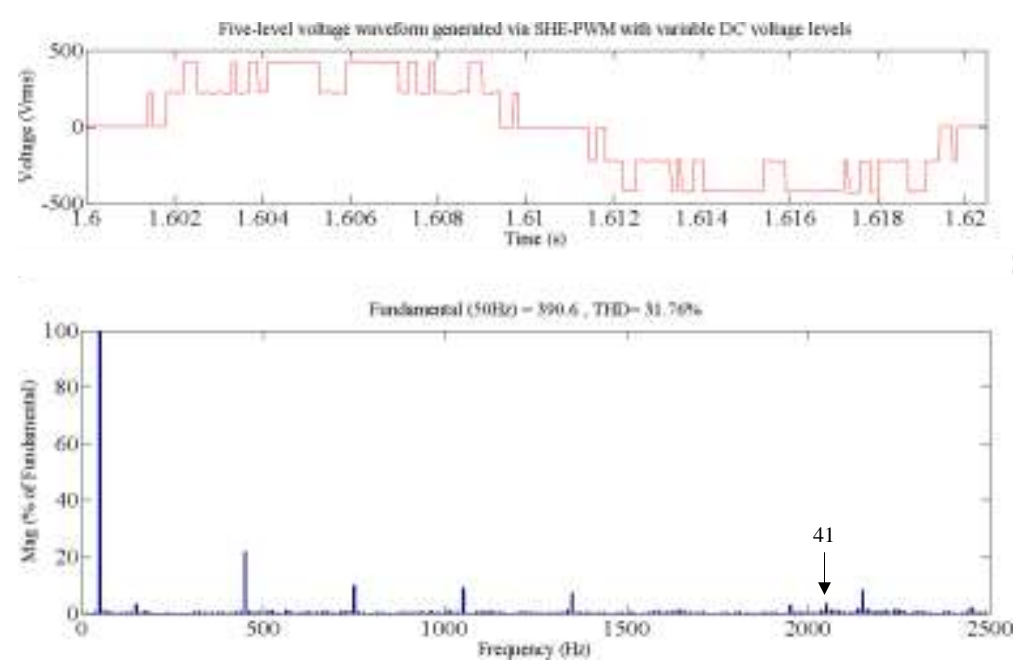

Figure 4. Simulation result of single-phase line-to-neutral five-levels SHE-PWM output voltage waveform and its harmonic spectrum

Figure 5 shows the steady-state characteristics of the proposed MSHEPWM STATCOM with separated flyback converters controlled by the proposed control schemes from load A to load B.

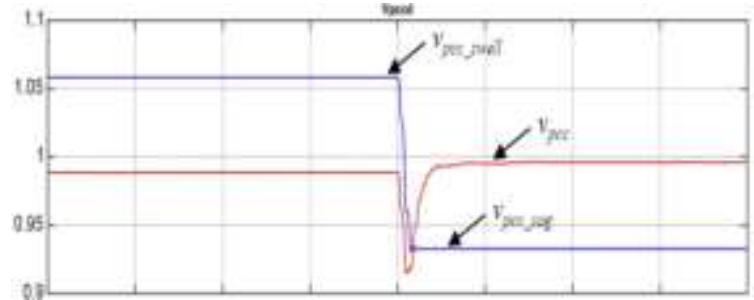

(a)

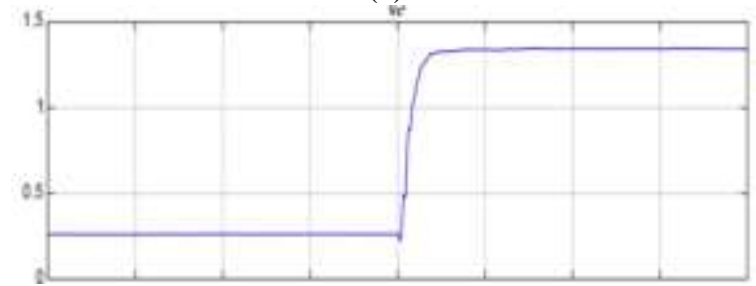

(c)

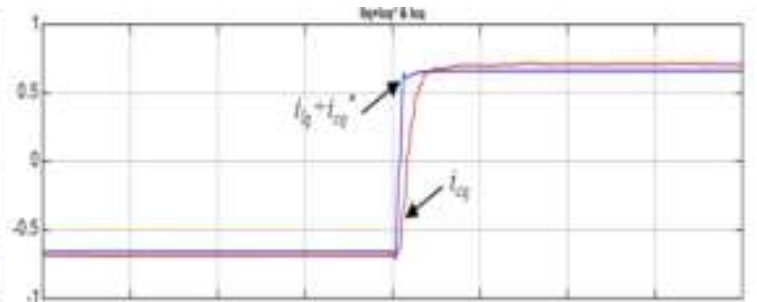

(b)

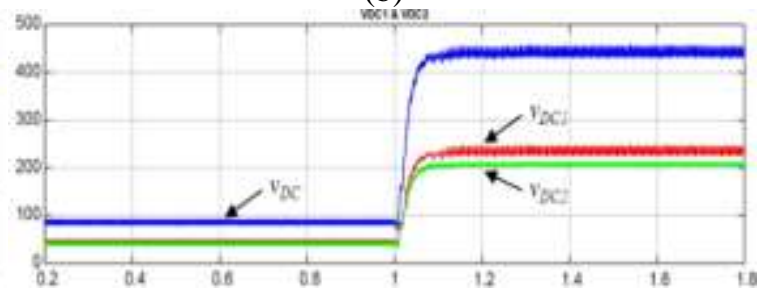

(d)

Figure 5. Simulation results of (a) grid voltage magnitude $v_{p c c}$, (b) ramp change of STATCOM reactive current $i_{c q}$ and its references $i_{l q}+i_{c q}{ }^{*}$, (c) modulation index $m_{i}$ and (d) flyback converters' output voltages $v_{D C l}$ and $v_{D C 2}$ at different loading conditions

Specifically, Figure 5(a) shows the grid voltage swells and sags (i.e., varied about 5\% from the nominal voltage value) which arisen when the load is switched from A to B. Figure 5(b) shows the characteristic of the proposed STATCOM with separated DC-DC flyback converters, where the STATCOM reactive current $i_{c q}$ is consistently tracing the ramp-change of the STATCOM's reactive current references $i_{l q}+i_{c q}{ }^{*}$ at different loading conditions. The characteristic of each DC output voltage (i.e., $v_{D C 1}$ and $v_{D C 2}$ ) generated by the proposed flyback converter in response to the resulting modulation index $m_{i}$ (see Figure 5(c)) produced by the proposed decoupled dq vector control are demonstrated in Figure 5(d). It is as predicted that good dynamics, steady-state and transient performances can be achieved when the proposed converters incorporated with the STATCOM's H-bridge cells are controlled by the proposed control schemes and modulation technique. 


\section{CONCLUSION}

A novel transformer-less single phase five-levels CHI based STATCOM with separated DC-DC flyback converter controlled by the proposed decoupled dq vector control, MSHEPWM technique and the voltage closed loop control was investigated in this work. The proposed MSHEPWM technique eases the implementation for dynamic systems by eliminating the tedious steps of the off-line calculations of switching angles. However, as the technique depends on adjustable DC-link voltage levels, the flyback converters controlled via the proposed voltage mode closed loop controller are implemented to achieve that. Nevertheless, DC-DC flyback converter demonstrated the advantage of being able to generate both higher and lower DC voltage from its input voltage; hence, increasing the feasibility of the STATCOM of providing leading and lagging VAR compensation to the PCC. In addition, together with the proposed dq vector controller incorporating the novel reactive current reference algorithm, good dynamic and transient responses were attained at both the capacitive and inductive loading conditions.

\section{REFERENCES}

[1] J. Dixon, et al., "Reactive power compensation technologies: state-of-the-art review," in Proceedings of the IEEE, vol. 93, pp. 2144-2164, 2005.

[2] A. Edris, et al., "Proposed terms and definitions for flexible AC transmission system (FACTS)," IEEE Transaction on Power Delivery, vol. 12, pp. 1848-1853, 1997.

[3] K. M. Islam and A. H. Samra, "Effect of condensers on harmonic propagation in AC power system," in Proceedings of IEEE Visualize the Future, pp. 425-428, 1995.

[4] M. Chindris, et al., "Propagation of unbalanced in electric power systems," in proceedings of IEEE International Conference on Electrical Power Quality and Utilization, pp. 1-5, 2007.

[5] Y. Cheng and M. L. Crow, "A diode-clamped multi-level inverter for the StatCom/BESS," in IEEE Power Engineering Society Winter Meeting, pp. 470-475, 2002.

[6] A. A. Siada and C. Karunar, "Improvement of transmission line power transfer capability, case study," An International Journal, vol/issue: 1(1), pp. 495-499, 2012.

[7] G. Escobar, et al., "An adaptive controller in stationary reference frame for D-STATCOM in unbalanced operation frame for D-STATCOM in unbalanced operation," IEEE Transactions on Industrial Electronics, vol. 51, pp. 401409, 2004.

[8] K. R. Padiyar, "FACTS controllers in power transmission and distribution," New Age, India, Anshan, 2007.

[9] Lab-Volt, "Static Synchronous Compensator-courseware sample,", 2012. [Online]. Available: www.labvolt.com/downloads/86371_F0.pdf

[10] D. Soto and C. G. Green, "A comparison of high-power converter topologies for the implementation of FACTS controllers," IEEE Transactions on Industrial Electronics, vol. 49, pp. 1072-1080, 2002.

[11] M. A. Parker, et al., "Fault-tolerant control for a modular generator-converter scheme for direct-drive wind turbines", IEEE Transactions on Industrial Electronics, vol. 58, pp. 305-315, 2010.

[12] Y. H. Liao and C. M. Lai, "Newly-constructed simplified single-phase multistring multilevel inverter topology for distributed energy resources," IEEE Transaction on Power Electronics, vol. 29, pp. 2386-2392, 2011.

[13] X. B. Yuan, et al., "A transformer-less high-power converter for large permanent magnet wind generator systems," IEEE Transactions on Sustainable Energy, vol. 3, pp. 318-329, 2012.

[14] J. C. Wu and C. W. Chou, "A solar power generation system with a seven-level inverter," IEEE Transaction on Power Electronics, vol. 29, pp. 3454-3462, 2013.

[15] R. Uthirasamy, et al., "Structure of boost DC-link cascaded multilevel inverter for uninterrupted power supply applications," IET Power Electronics, vol. 8, pp. 2085-2096, 2015.

[16] E. Zamiri, et al., "A new cascaded switched-capacitor multilevel inverter based on improved series-parallel conversion with less number of components," IEEE Transactions on Industrial Electronics, vol. 63, pp. 3582-3594, 2016.

[17] K. H. Law, et al., "A new reactive current reference algorithm for STATCOM system based on cascaded multilevel inverters," IEEE Transactions on Power Electronics, vol. 30, pp. 3577-3588, 2014.

[18] K. H. Law, et al., "SHE-PWM cascaded multilevel inverter with adjustable DC-voltage levels control for STATCOM applications," IEEE Transactions on Power Electronics, vol. 29, pp. 6433-6444, 2014.

[19] F. Deng and Z. Chen, "Control of Improved Full-Bridge Three-Level DC/DC Converter for Wind Turbines in a DC Grid," IEEE Transactions on Power Electronics, vol. 28, pp. 314-324, 2012.

[20] L. Zhang, et al., "A Modular Grid-Connected Photovoltaic Generation System Based on DC Bus," IEEE Transactions on Power Electronics, vol. 26, pp. 523-531, 2010.

[21] H. Akagi and R. Kitada, "Control and design of a modular multilevel cascade BTB system using bidirectional isolated DC/DC converters," IEEE Transactions on Power Electronics, vol. 26, pp. 2457-2464, 2011.

[22] Texas Instruments, "Voltage Fed Full Bridge DC-DC and DC-AC Converter for High-Frequency Inverter Using C2000," [Online]. Available: www.ti.com/lit/an/sprabw0a/sprabw0a.pdf 


\section{BIOGRAPHIES OF AUTHORS}
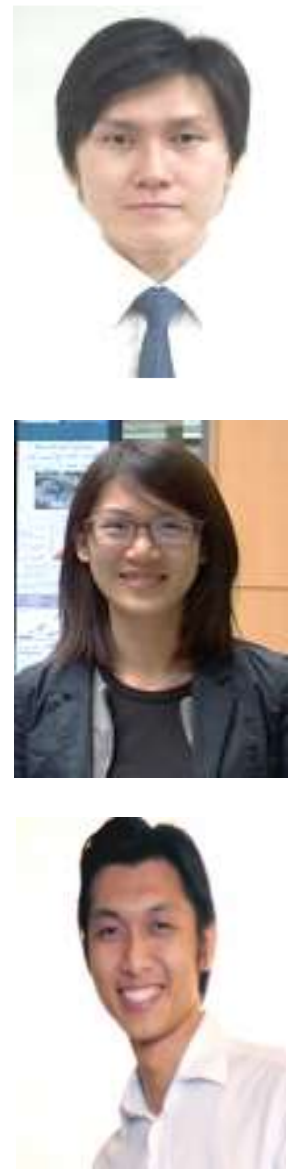

Law Kah Haw received his Advanced Diploma from Riam Institute of Technology, Sarawak in 2007, Master in Engineering and PhD from the University of Nottingham, UK in 2010 and 2015, respectively. His research interest includes power electronics, drives, and advance control system. His current research work focused on control schemes and optimization for quasi Z source and multilevel inverter topologies.

Wendy $\mathrm{Ng}$ received her Master in Engineering and Ph.D. in Engineering from The University of Nottingham. Her research interest includes process synthesis and design, process modelling and and supply network optimization. Her current research work concentrated on palm biomass utilization and optimization. Her research mainly develops novel, sustainable and economical biomass utilisation strategy for practical application. She worked in the industry prior to joining Curtin as a lecturer.

WK Wong received his PHD in 2016 from Universiti Malaysia Sabah (UMS). Prior to his involvement in Academia, he was an Electrical Engineer in Construction industry. WK Wong research interest includes Robotics, Imaging Artificial Intelligence and Evolutionary Programming. 